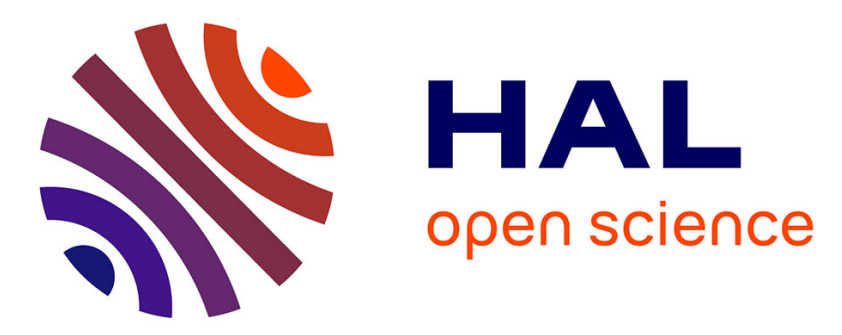

\title{
A new stem Orthoptera (Archaeorthoptera: Oedischioidea) from the Early Permian of the Saar-Nahe basin, southwest Germany
}

André Nel, Markus Poschmann

\section{- To cite this version:}

André Nel, Markus Poschmann. A new stem Orthoptera (Archaeorthoptera: Oedischioidea) from the Early Permian of the Saar-Nahe basin, southwest Germany. Geobios, 2020, 63, pp.47-52. 10.1016/j.geobios.2020.10.001 . hal-03146600

\section{HAL Id: hal-03146600 https: / hal.sorbonne-universite.fr/hal-03146600}

Submitted on 19 Feb 2021

HAL is a multi-disciplinary open access archive for the deposit and dissemination of scientific research documents, whether they are published or not. The documents may come from teaching and research institutions in France or abroad, or from public or private research centers.
L'archive ouverte pluridisciplinaire HAL, est destinée au dépôt et à la diffusion de documents scientifiques de niveau recherche, publiés ou non, émanant des établissements d'enseignement et de recherche français ou étrangers, des laboratoires publics ou privés. 
2 A new stem Orthoptera (Archaeorthoptera: Oedischioidea) from the Early Permian of the Saar-

3 Nahe basin, southwest Germany

4

5

6

7

8

9

André $\mathrm{Nel}^{\mathrm{a}}$, Markus J. Poschmann ${ }^{\mathrm{b}}$

${ }^{a}$ Institut de Systématique, Evolution, Biodiversité (ISYEB), Muséum national d'Histoire naturelle, CNRS, Sorbonne Université, EPHE, Université des Antilles, CP 50, 57 rue Cuvier, 75005 Paris, France. E-mail: anel@mnhn.fr

${ }^{b}$ Generaldirektion Kulturelles Erbe RLP, Direktion Landesarchäologie/Erdgeschichte, Niederberger Höhe 1, D-56077 Koblenz, Germany; E-mail: markus.poschmann@gdke.rlp.de

\section{ABSTRACT}

The new oedischiine Palatinoedischia elongata nov. gen., nov. sp. is described from the Early Permian of Germany. It is characterized by a very particular broad area between $\mathrm{R}+\mathrm{M}+\mathrm{CuA}$ and $\mathrm{CuP}$ of the tegmen. The possible closest relative is the genus Plesioidischia, also from the Early Permian of Germany. They possibly constitute their own clade, but a phylogenetic analysis is needed to clarify the whole superfamily Oedischioidea.

Keywords: Insecta; Oedischiidae; Palatinoedischia elongata gen. et sp. nov.; Lower Rotliegend; Saar-Nahe basin.

\section{Introduction}

The Oedischioidea Handlirsch 1906 is a rather diverse group of Orthoptera, currently known from the Late Carboniferous to the Early Jurassic. Its monophyly and limits, and the 
composition of the different included families are questionable (Béthoux and Nel, 2002b: 224).

A new phylogenetic analysis is needed to solve these important questions, crucial to clarify the phylogeny of the Orthoptera, because, depending on the authors, this superfamily is considered as belonging to the stem group of the Orthoptera or of the Ensifera. Also, depending on the authors (see fossilworks database), the Oedischioidea would comprise the Oedischiinae Handlirsch, 1906, Elcanoedischiinae Gorochov, 1987a, Mezenoedischiinae Gorochov, 1987a, Mesoedischiidae Gorochov, 1987b, Bintoniellidae Handlirsch, 1939, Proparagryllacrididae Riek, 1956, Pruvostitidae Zalessky, 1928 (= Pruvostitinae Zalessky, 1928, Sylvoedischiinae Gorochov, 1987a, Kamiinae Sharov, 1968, Kargalariinae Gorochov, 1995, Maculoedischiinae Gorochov, 1987a, Tettavinae Sharov, 1968), and the Tcholmanvissiidae Zalessky, 1934 (= Tcholmanvissiinae Zalessky, 1934, Tettoedischiinae Gorochov 1987a).

The Late Carboniferous oldest fossil Orthoptera are attributed to this superfamily. It greatly diversified during the Permian. Depending of the confirmation of its monophyly, this superfamily survived the Permian-Triassic mass extinction.

It is also important to better define the limits and Permian diversity of this group through a phylogenetic analysis, in order to estimate the evolutionary changes that could have occurred during the Carboniferous, Permian, and Triassic.

Here we describe a new Early Permian fossil from the Saar-Nahe basin in southwest Germany that belongs to this group but shows some very particular forewing venational structures.

\section{Material and methods}

The specimen has been found by one of us (MJP) at a locality situated between the villages of Sitters and Schiersfeld in the Moschelbach valley/Rhineland-Palatinate (Fig. 1). Poschmann and Schindler (2004) described a nearby situated locality "Sitters", which is slightly 
older than the one that yielded the present specimen. The fossil described here originates from the younger "Niedermoschel black shale" sensu Schindler (1997), stratigraphically belonging to the informal unit M5 of the Jeckenbach Subformation, Meisenheim Formation, Glan Subgroup of the Lower Rotliegend (Boy et al., 2012, Fig. 1).

The Niedermoschel black shale is known since the early $20^{\text {th }}$ century (Reis, 1913). Schindler (1997) characterized it in a stratigraphical context and Poschmann and Schindler (1997) described this unit in terms of lithology and palaeoecology. The type locality yielded plant remains (Uhl, 2008), a variety of vertebrates (e.g., Hampe, 1996, Poschmann and Schindler, 1997) such as fishes and rare branchiosaurs. It is extraordinary for the rich occurrence of arthropods such as ostracods, spinicaudatans, syncarid crustaceans (Uhl, 1999), xiphosurids (Malz and Poschmann, 1993), and insects (Hörnschemeyer, 1999). The terrestrial insect remains were introduced into a lacustrine environment influenced by deltaic input and comprise a large number of lemmatophorids, Blattinopsidae (Hörnschemeyer and Stapf, 2001), and Miomoptera (Hörnschemeyer, 1999; Brauckmann, 2007). Most of the insect fossils are wings less than two centimeters long. An exceptionally preserved stem orthopteran, Nosipteron niedermoschelensis Béthoux and Poschmann, 2009, has also been described from there. The new locality near Sitters, which yielded the stem orthopteran described herein, shows essentially the same suite of fossils encompassing plant remains, fishes, conchostracans, xiphosurids, and insects. No detailed scientific exploration is available as yet. The sediments at both localities show contact-metamorphism, which greatly enhanced the recognizability of the insect remains as they appear as shiny, silvery fossils on the dark, gray-bluish matrix (Montenary and Uhl, 2005 concerning preservation).

In fact, the Early Permian insects from "Odernheim town site" described by Prokop et al. (2012) originate from various localities in the Rotliegend of the Saar-Nahe basin (K.-D. Weiß, pers. comm.). Some of these may originate from the Niedermoschel black shale as well. 

binocular microscope. It was coated with $\mathrm{MgO}$, photographed using a Canon 600D digital camera equipped with a canon EFS 60mm macro lens and drawn using a Leica drawing tube attached to the microscope. Photographs with differing planes of focus were stacked into a composite with enhanced depth of field using the free software CombineZP by Alan Hadley.

We follow the classification and wing venation terminology of Béthoux and Nel (2002a) and Schubnel et al. (2020) for the Archaeorthoptera. Abbreviations: C costa; ScA subcosta anterior; ScP subcosta posterior; RA radius anterior; RP radius posterior; MA median anterior; MP median posterior; $\mathrm{CuA}$ cubitus anterior; $\mathrm{CuP}$ cubitus posterior; $\mathrm{PCu}$ postcubital vein; $\mathrm{AA}$ anal veins.

urn:lsid:zoobank.org:pub:F2195993-BA7A-4BC3-8342-EF6E6AEEB13E

\section{Systematic palaeontology}

Clade Archaeorthoptera Béthoux and Nel, 2002

Order Orthoptera Olivier, 1789

Superfamily Oedischioidea Handlirsch, 1906

Family Oedischiidae Handlirsch, 1906

Subfamily Oedischiinae Handlirsch, 1906

Genus Palatinoedischia nov.

urn:1sid:zoobank.org:act:066637A2-A1FE-43E0-9D3B-6E969F85CE7C

Derivation of the name: Named after the Palatinate, the region where the type locality is, and Oedischia. Gender feminine.

Type species: Palatinoedischia elongata nov. gen., nov. sp.

Diagnosis: Tegmen characters only. Tegmen narrow elongate; a well-defined vein ScA; veins in area between $\mathrm{ScA}$ and $\mathrm{ScP}$ all simple and straight; ScP with short branches; distal anterior 
branches of RA short; two to four rows of irregular cells in very broad area between $\mathrm{R}+\mathrm{M}+\mathrm{CuA}$ and $\mathrm{CuP}$, much broader than that between $\mathrm{M}$ and $\mathrm{CuA}+\mathrm{CuPa} \alpha$; anterior branch MA1 of MA shortly connected to RP; two branches of MA basal of MA1; basal part of CuA elongate; $\mathrm{CuPa} \beta$ 'rudimentary' near its base, partly 'lost' in a net of irregular cells; no supplementary independent branch basal to fusion of $\mathrm{CuPa} \alpha$ with $\mathrm{CuA}$.

Palatinoedischia elongata nov. gen., nov. sp.

Figs 2, 3

urn:1sid:zoobank.org:act:A73201ED-ADFC-418D-A64E-DE1ACD0E2C7F

Derivation of the name: Named 'elongata' after the narrow elongate tegmen.

Holotype: PE 2018/5000-LS, State Collection of Natural History of Rhineland-Palatinate, Mainz (original collector's number 751-P; see Brauckmann, 2007). Part and counterpart of a nearly complete forewing, very well-preserved with only extreme base and parts of costal and posterior margins missing.

Type horizon and locality: Early Permian, Lower Rotliegend, Meisenheim Formation, Jeckenbach Subformation, Niedermoschel black shale (sensu Schindler, 1997), probably Asselian-?Sakmarian (Schneider and Werneburg, 2012, Schneider et al., 2020); Saar-Nahe Basin south of Sitters, Germany.

Diagnosis: As for the genus by monotypy.

Description: Tegmen $62.3 \mathrm{~mm}$ long, $10.7 \mathrm{~mm}$ wide, rather narrow elongate and slightly falcate; a well-defined ScA, $10.6 \mathrm{~mm}$ long; area between C and ScA poorly preserved, ca. $1.4 \mathrm{~mm}$ wide; crossveins between $\mathrm{ScA}$ and $\mathrm{ScP}$ simple, straight and short, perpendicular to $\mathrm{ScP}$ and $\mathrm{ScA}$, those between ScP and C poorly preserved, but apparently also short; area between costal margin and ScP ca. $1.7 \mathrm{~mm}$ wide; base of RP $27.0 \mathrm{~mm}$ distal of wing base; ScP and $\mathrm{R}+(\mathrm{M}+\mathrm{CuA})$ well separated, $1.2 \mathrm{~mm}$ apart with numerous straight crossveins in between; $\mathrm{ScP}$ 
probably ending in $\mathrm{C}$; presence of a basal common stem $\mathrm{R}+\mathrm{M}+\mathrm{CuA}$ but $\mathrm{R}$ and $\mathrm{M}+\mathrm{CuA}$ separating close to wing base, with a $0.7 \mathrm{~mm}$ wide area in-between at level of separation of $\mathrm{M}$ with $\mathrm{CuA}$; RA convex, simple, with a narrow distal area with short veinlets between it and C; broad area between RA and RP with strongly curved crossveins, $2.6 \mathrm{~mm}$ wide; RP rather concave; distance between its base and point of fusion with MA1 $7.3 \mathrm{~mm}$; RP+MA1 $0.8 \mathrm{~mm}$ long; MA1 long and straight, with an apical fork; RP with five branches; CuA separated from $\mathrm{M}$ in basal third of wing, at $13.8 \mathrm{~mm}$ from wing base; basal stem of $\mathrm{M}$ very short, $0.6 \mathrm{~mm}$ long; neutral MA with three distal branches, most basal one simple, second forked; and third (MA1 ending into RP and separating again distally; concave MP simple; CuA fused with CuPa 2.5 $\mathrm{mm}$ of its base; $\mathrm{CuA}+\mathrm{CuPa} \alpha$ posteriorly pectinate, with three visible branches; $\mathrm{CuPa}$ long basal of its fusion with $\mathrm{CuA}, 4.7 \mathrm{~mm}$ long; $\mathrm{CuPa} \beta$ simple, well discernible as a vein distinctly wider than crossveins at its base, but poorly defined distally and partly lost in an irregular net of cells in a broad area between $\mathrm{CuA}+\mathrm{CuPa} \alpha$ and $\mathrm{CuPb}$; division of $\mathrm{CuP}$ into $\mathrm{CuPa}$ and $\mathrm{CuPb} 10.6 \mathrm{~mm}$ from wing base; $\mathrm{CuPb}$ simple; $\mathrm{PCu}$ and two anal veins, all simple; area between $\mathrm{R}+\mathrm{M}+\mathrm{CuA}$ and $\mathrm{CuP}$ very broad, $2.9 \mathrm{~mm}$ wide, with a net of 3-4 rows of irregular cells in-between.

\section{Discussion}

This forewing corresponds to that of a clade Panorthoptera Crampton, 1928 sensu Béthoux and Nel (2002a: 27) because of the following synapomorphies: CuPa differentiated into two branches $(\mathrm{CuPa} \alpha$ and $\mathrm{CuPa} \beta)$ just basal of the fusion of the anterior one $(\mathrm{CuPa} \alpha)$ with $\mathrm{CuA}$ (synapomorphy of Panorthoptera); ScP probably reaching anterior wing margin and not RA; MA1 and MA2 can be differentiated; $\mathrm{CuA}+\mathrm{CuPa} \alpha$ with at least two posterior branches; $\mathrm{CuPb}$ simple. Palatinoedischia nov. gen. shares with the Orthoptera (sensu Béthoux and Nel, 2002a: 38-39) the MA forked; $\mathrm{MP}, \mathrm{CuPa} \beta, \mathrm{CuPb}$, and PCu simple. 
Nevertheless, the vein $\mathrm{CuPa} \beta$ is 'rudimentary' near its base, partly 'lost' in a net of

151

152

153

154

155

156

157

158

159

160

161

162

163

164

165 irregular cells. Similar 'aberrant' situations can occur for some other Permian Orthoptera, e.g., 'Tettoedischia minuta Sharov, 1968, undoubtedly closely related to Macroedischia within Tettoedischiinae, has a free and simple $\mathrm{CuPa} \alpha$, without any clear anterior branch reaching CuA'; Béthoux and Nel, 2002b: 224). A similar situation occurs in the panorthopteran family Geraridae Scudder, 1885 (Béthoux and Nel, 2003). The pattern of venation fits quite well with those of the Oedischiinae, in the presence of a well-defined vein ScA, a series of regular crossveins in subcostal area and area between ScP and R/RA, ScP and RA well separated, broad areas between RA and RP and between R/RP and MA, and basal fork of M very close to point of separation between $\mathrm{M}$ and $\mathrm{CuA}$. We consider that the venation of Palatinoedischia nov. gen. is compatible with an attribution to the Orthoptera.

Palatinoedischia nov. gen. has two to four rows of irregular cells in the area between $\mathrm{R}+\mathrm{M}+\mathrm{CuA}$ and $\mathrm{CuP}$, while nearly all the described Oedischioidea have a distinctly narrower area with one row of cells. A similar situation occurs in Gerarus Scudder, 1885. Palatinoedischia nov. gen. strongly differs from the Geraridae in the simple $\mathrm{MP}$ and $\mathrm{CuPb}$, narrow elongate tegmen, and very short stem of M (Béthoux and Nel, 2003).

Also, affinities with the Tcholmanvissiidae sensu Béthoux and Nel (2002b) are excluded because Palatinoedischia nov. gen. has an anterior branch of MA ending into RP, and no supplementary independent branch basal to fusion of $\mathrm{CuPa} \alpha$ with $\mathrm{CuA}$. The Bintoniellidae and the Proparagryllacrididae also have no anterior branch of MA ending into RP (Riek, 1955, 1956, 1976; Sharov, 1968; Gorochov, 1987b, 1989, 2013; Béthoux and Beckemeyer, 2007).

The Mezenoedischiinae have a narrow area between MP and the anterior stem of CuA $+\mathrm{CuPa} \alpha$, and the presence of only one branch of MA posterior to base of MA1, unlike two in Palatinoedischia nov. gen. (Carpenter, 1966; Sharov, 1968; Gorochov, 1987a; Béthoux et al., 2002; Béthoux and Beckemeyer, 2007). The Elcanoedischiinae (Kansasoedischia Gorochov 
1987a, Elcanoedischia Gorochov 1987a, Metoedischia Martynov 1928); and the Sylvoedischiinae (Stenoedischia Gorochov 1987a, Sylvoedischia Sharov 1968) differ from Palatinoedischia nov. gen. in the presence of only one branch of MA posterior to base of MA1 (Martynov, 1928; Sharov, 1968; Gorochov, 1987a). The Sylvoedischiinae also have broader tegmina compared to their length. The Pruvostitidae have ScP with longer branches than in Palatinoedischia nov. gen., and either only one branch of MA posterior to base of MA1 and/or a long basal stem of $\mathrm{M}$ before its separation into MA and MP, and/or no fusion between anterior branch of MA and RP, unlike Palatinoedischia nov. gen. (Zalessky, 1929; Gorochov, 1987a,c, 2013). The Mesoedischiidae also have a long stem of M (Sharov, 1968; Gorochov, 2005).

The Oedischiinae Handlirsch, 1906 have a short stem of M as in Palatinoedischia nov. gen. Oedischia Handlirsch, 1906 has only one branch of MA posterior to base of MA1 (Sharov, 1968). Sinoedischia Hong, 1985 has such two branches, but the basal half of the tegmen is not preserved, so that the length of basal part of $\mathrm{M}$ and the pattern of the cubital veins are unknown, rendering the position of this taxon uncertain (Hong, 1985: figs 29-30). Anhomalophlebia Handlirsch, 1919 has a basal stem of M longer than in Palatinoedischia nov. gen. and no fusion of a branch of MA with RP (see figure in the internet site http://mediaphoto.mnhn.fr/media/14986360852690vFhvxWDuH8srHmM). Afroedischia Geertsema and van Dijk, 1999 has a very long stem of M, and no fusion of a branch of MA with RP (Geertsema and van Dijk, 1999: figs 1-2). Anelcana Carpenter, 1986 (replacement name for Parelcana Carpenter, 1966) differs from Palatinoedischia nov. gen. in the area between $\mathrm{ScA}$ and $\mathrm{ScP}$ quite narrow, a very short basal part of $\mathrm{CuA}$ and a short $\mathrm{CuPa} \beta$ (Carpenter, 1966: fig. 19). Kamaites Zalessky, 1929 is based on a very incomplete wing not showing the essential structures to be compared to the other Orthoptera (Zallesky, 1929: fig. 9). Nobloedischia Beckemeyer, 2011a differs from Palatinoedischia nov. gen. in the presence of only one branch of MA posterior of MA1, presence of long anterior branches of RA, narrower 
areas between $\mathrm{R}+\mathrm{M}+\mathrm{CuA}$ and $\mathrm{CuP}$ and between $\mathrm{CuPa}$ and $\mathrm{CuPb}$ (Beckemeyer, 2011a: figs 13). Scalaeoptera Bolton, 1922 is based on a very fragmentary tegmen, impossible to compare to the other Paleozoic Orthoptera (Bolton, 1922: fig. 27). Xeroptera Bolton, 1922 is also based on an incomplete tegmen; it possibly does not belong to the Archaeorthoptera but to a very different group, the Paoliida (sensu Prokop et al., 2014), because it has a series of anterior branches of $\mathrm{CuA}$, a rather broad area between $\mathrm{CuA}$ and $\mathrm{CuP}$, and apparently no branches of $\mathrm{CuP}$ ending into $\mathrm{CuA}$ (Bolton, 1922: fig. 26). This taxon needs to be revised.

Loxoedischia Beckemeyer, 2011b shares many characters with Palatinoedischia nov. gen. in the pattern of the veins $\mathrm{Cu}$ and $\mathrm{M}, \mathrm{ScP}$ and $\mathrm{ScA}$. Nevertheless, it has anterior branches of RP, no branch of MA ending into RP (Beckemeyer, 2011b: fig. 1).

The tegmen of Plesioidischia baentschi Schlechtendal, 1906 (in Handlirsch, 1906) from the upper Meisenheim or Disibodenberg Formation of Nonnweiler near Birkenfeld/Nahe, revised by Guthörl (1934: fig. 58), greatly resembles that of Palatinoedischia nov. gen., with only the following differences: the area between $\mathrm{R}+\mathrm{M}+\mathrm{CuA}$ and $\mathrm{CuP}$ is only slightly wider than that between $\mathrm{M}$ and $\mathrm{CuA}+\mathrm{CuPa} \alpha$, the veins in area between $\mathrm{ScA}$ and $\mathrm{ScP}$ are clearly irregular while they are all simple and straight in Palatinoedischia nov. gen. Bolton (1922: 9293, text-fig. 29, pl. 6, fig. 3) described and figured a Plesioidischia sp. from the 'Middle Coal Measures (binds between 'Brooch' and 'Thick' coals); Tipton, Staffs' in UK. This fossil is the basal third of a tegmen, but it does not show the broadened area between $\mathrm{R}+\mathrm{M}+\mathrm{CuA}$ and $\mathrm{CuP}$ of Plesioidischia baentschi. It probably corresponds to a different genus; we consider it as an Oedischioidea incertae sedis.

\section{Conclusion}

Palatinoedischia nov. gen. does not fit with any of the described Oedischioidea. It seems to be close to Plesioidischia baentschi because of the great similarities in the wing venations. 
Plesioidischia is also known from the early Permian of Germany, but the new fossil clearly corresponds to a different genus and species. Both could belong to the same clade, characterized by the broadened area between $\mathrm{R}+\mathrm{M}+\mathrm{CuA}$ and $\mathrm{CuP}$. We provisionally attribute it to the Oedischiinae, but a phylogenetic analysis of the whole Oedischioidea is necessary to clarify the relationships and definitions of its different components. The monophyly of the whole group and its components are questionable. Thus the comparison of any new taxon to the different families and genera can only be based on similarities and not on well-defined synapomorphies.

\section{Acknowledgements}

We sincerely thank two anonymous referees for the useful comments on the first version of the paper. MJP thanks Dr. Thomas Schindler (Spabrücken) for joint fieldwork, Sabine Treptow (Waldesch) for help with graphics, and Klaus-Dieter Weiß (Fischbach) for useful hints.

\section{References}

Beckemeyer, R.J., 2011a. Nobloedischia rasnitsyni, a new genus and species of Oedischiidae (Orthoptera) from the Lower Permian Wellington Formation of Oklahoma, USA. In: Shcherbakov, D.E., Engel, M.S., Sharkey, M.J. (eds). Advances in the systematics of fossil and modern insects: Honouring Alexandr Rasnitsyn. ZooKeys 130, 103-110.

Beckemeyer, R.J., 2011b. A new genus and species of Orthoptera from the Lower Permian Wellington Formation of Noble County, Oklahoma, USA. Transactions of the Kansas Academy of Science 114, 88-94.

Béthoux, O., Beckemeyer, R.J., 2007. New and rare insect species from the Wellington Formation (Orthoptera, Grylloblattodea; Lower Permian, USA). Alavesia 1, 49-61.

Béthoux, O., Nel, A., 2002a. Venation pattern and revision of Orthoptera sensu nov. and sister groups. Phylogeny of Palaeozoic and Mesozoic Orthoptera sensu nov. Zootaxa 96, 1-88. 
Béthoux, O., Nel, A., 2002b. New data on Tcholmanvissiidae (Orthoptera; Permian). Journal of Orthoptera Research 11, 223-235.

Béthoux, O., Nel, A., 2003. Wing venation morphology and variability of Gerarus fischeri (Brongniart, 1885) sensu Burnham (Panorthoptera; Upper Carboniferous, Commentry, France), with inferences on flight performance. Organisms Diversity and Evolution 3, 173-183.

Béthoux, O., Nel, A., Gand, G., Lapeyrie, J., Galtier, J., 2002. Discovery of the genus Iasvia Zalessky, 1934 in the Upper Permian of France (Lodève basin) (Orthoptera: Ensifera: Oedischiidae). Geobios 35, 293-302.

Béthoux, O., Poschmann, M., 2009. A new lobeattid insect from the Permo-Carboniferous of Niedermoschel, southwestern Germany (Archaeorthoptera). Journal of Orthoptera Research 18, $139-143$.

Bolton, H., 1922. A monograph of the fossil insects of the British coal measures. Palaeontographical Society Monograph, London 74, 81-156.

Boy, J.A., Haneke, J., Kowalczyk, G., Lorenz, V., Schindler, T., Stollhofen, H., Thum, H., 2012. Rotliegend im Saar-Nahe-Becken, am Taunus-Südrand und im nördlichen Oberrheingraben. In: Deutsche Stratigraphische Kommission (eds.) Stratigraphie von Deutschland X. Rotliegend. Teil I: Innervariscische Becken. Schriftenreihe der Deutschen Gesellschaft für Geowissenschaften 61, 254-377.

Brauckmann, C., 2007. Die Insekten im Permokarbon des Saar-Nahe-Beckens. In: Schindler, T., Heidtke, U.H.J. (eds.) Kohlesümpfe, Seen und Halbwüsten. Dokumente einer rund 300 Millionen Jahre alten Lebewelt zwischen Saarbrücken und Mainz. POLLICHIA Sonderveröffentlichung 10, 170-196.

Carpenter, F.M., 1966. The Lower Permian insects of Kansas. Part 11. The orders Protorthoptera and Orthoptera. Psyche 73, 46-88. 
274 Carpenter, F.M., 1986. Substitute names for the extinct genera Cycloptera Martynova 275 (Mecoptera) and Parelcana Carpenter (Orthoptera). Psyche 93, 375-376.

276 Crampton, G.C., 1928. The grouping of the insect orders and their lines of descent. The 277 Entomologist 61, 82-85.

278 Geertsema, H., Van Dijk, D.E., 1999. The earliest known Palaeozoic ensiferan insect from 279 Africa, Afroedischia oosthuizeni gen. et sp. n. (Orthoptera: Oedischiidae). South African 280 Journal of Science 95, 229-230.

Gorochov, A.V., 1987a. Permian Orthoptera of the infraorder Oedischiidea (Ensifera).

Paleontological Journal 21, 65-75.

Gorochov, A.V., 1987b. New fossil orthopterans of the families Bintoniellidae, Mesodischiidae fam. n. and Pseudoelcanidae fam. n. (Orthoptera, Ensifera) from Perm and Triassic deposits of the USSR. Vestnik Zoologii 25, 18-23. [in Russian, with English summary.]

Gorochov, A.V., 1987c. New fossil orthopterans of the families Adumbratomorphidae fam. n., Pruvostitidae and Proparagryllacrididae (Orthoptera, Ensifera). Vestnik Zoologii 25, 20-28. [in Russian, with English summary.]

Gorochov, A.V., 1989. New taxa of the orthopteran families Bintoniellidae, Xenopteridae, Permelcanidae, Elcanidae and Vitimiidae (Orthoptera, Ensifera). Vestnik Zoologii 27, 20-27. [in Russian.]

Gorochov, A.V., 1995. Sistema i evolyutsiya pryamokrylykh podotryada Ensifera (Orthoptera) [System and Evolution of the suborder Ensifera (Orthoptera).] Parts 1 and 2. Trudy Zoologicheskogo Instituta [Russian Academy of Sciences, Proceedings of the Zoological Institute] 260, 3-224 + 261: 3-212. [in Russian]

Gorochov, A.V., 2005. Review of Triassic Orthoptera with descriptions of new and little known taxa: part 1. Paleontological Journal 39, 178-186. 
Gorochov, A.V., 2013. New taxa of the superorder Orthopteroidea from the latter half of the

299 Permian of European Russia. Paleontological Journal 47, 782-793.

300

301

302

303

304

305

306

307

Guthörl, P., 1934. Die Arthropoden aus dem Karbon und Perm der Saar-Nahe-Pfalz-Gebietes. Abhandlungen des Koenigliche Preussichen Geologische Landesanstalt (N.F.) 164, 48-178.

Hampe, O., 1996. Dermale Skelettelemente von Lissodus (Chondrichthyes: Hybodontoidea) aus dem Unterperm des Saar-Nahe-Beckens. Paläontologische Zeitschrift 70, 225-243.

Handlirsch, A., 1906-1908. Die fossilen Insekten und die Phylogenie der rezenten Formen. Ein Handbuch für Paläontologen und Zoologen, 1430 pp.

Handlirsch, A., 1919. Revision der paläozoischen Insekten. Denkschriften der Kaiserlichen Akademie der Wissenschaften, Mathematisch-Naturwissenschaftliche Klasse 96, 511-592.

Handlirsch, A., 1939. Neue Untersuchungen über die fossilen Insekten mit Ergänzungen und Nachträgen sowie Ausblicken auf phylogenetische, paläogeographische und allgemeine biologische Probleme. Teil 2. Annalen des Naturhistorischen Museums in Wien 49, 1-240.

Hörnschemeyer, T., 1999. Fossil insects from the Lower Permian of Nierdermoschel (Germany). AMBA projects AM/PFICM98/1.99. Proceedings of the First International Palaeoentomological Conference, Moscow 1998, 57-59.

Hörnschemeyer, T., Stapf, H., 2001. Review of Blattinopsidae (Protorthoptera) with description of new species from the Lower Permian of Niedermoschel (Germany). Neues Jahrbuch für Geologie und Paläontologie Abhandlungen 221, 81-109.

Hong, Y.-c., 1985. [Insecta] pp. 489-510. In: [Palaeontological atlas of North China. 1. Paleozoic volume.] (ed. Tianjing Institute of Geology and Mineral Resources). Geological Publishing House, Beijing. [in Chinese.]

Malz, H., Poschmann, M., 1993. Erste Süßwasser-Limuliden (Arthropoda, Chelicerata) aus dem Rotliegenden der Saar-Nahe-Senke. Osnabrücker naturwissenschaftliche Mitteilungen 19, 21-34. 
Martynov, A.V., 1928. Permian fossil insects of North-East Europe. Trudy Geologicheskogo Muzeya Akademii nauk SSSR [Travaux du Musée Géologique près l'Académie des Sciences de l'URSS] 4, 1-118.

Montenari, M., Uhl, D., 2005. Mikroanalytische und rasterelektronenmikroskopische Untersuchungen zur Taphonomie von Arthropoden in „kontaktmetamorphen“ Sedimenten Erste Ergebnisse. Mitteilungen der Pollichia 91, 13-20.

Olivier, G.A., 1789. Encyclopédie Méthodique. Histoire naturelle, Tome Quatrième, Insectes, $1-331$.

Poschmann, M., Schindler, T., 1997. Ein Neufund von Fayolia sp. (Chondrichthyes: HaiEikapsel) mit paläoökologischen Anmerkungen zum Fundhorizont (Niedermoschel-Bank, Unteres Rotliegend; Saar-Nahe-Becken). Mainzer geowissenschaftliche Mitteilungen 26, 2536.

Poschmann, M., Schindler, T., 2004. Sitters and Grügelborn, two important FossilLagerstaetten in the Rotliegend (?Late Carboniferous - Early Permian) of the Saar-Nahe Basin (SW-Germany), with the description of a new palaeoniscoid (Osteichthyes, Actinopterygii). Neues Jahrbuch für Geologie und Paläontologie Abhandlungen 232, 283-314.

Prokop, J., Krzeminski, W., Krzeminska, E., Hörnschemeyer, T., Ilger, J.-M., Brauckmann, C., Grandcolas, P., Nel, A., 2014. Late Palaeozoic Paoliida is the sister group of Dictyoptera (Insecta: Neoptera). Journal of Systematic Palaeontology 12, 601-622.

Prokop, J., Weiß, K.-D., Dechambre, R.-P., Nel, A., 2012. Early Permian insects from SaarNahe Basin of Odernheim town site, Rheinland-Pfalz in Germany (Insecta, Grylloblattida, Blattinopseida). Geodiversitas 34, 271-281.

Reis, O.M., 1913. Über einige im Unter- und Oberrotliegenden des östlichen Pfälzer Sattels gefundene Tierreste. Geognostische Jahrreshefte 25, 237-254. 
Riek, E.F., 1956. A re-examination of the mecopteroid and orthopteroid fossils (Insecta) from the Triassic beds at Denmark Hill, Queensland, with descriptions of further specimens. Australian Journal of Zoology 4, 98-110.

Sanchez, S., Steyer, J.S., Schoch, R.R., De Ricqlès, A., 2010. Palaeoecological and palaeoenvironmental influences revealed by long-bone palaeohistology: the example of the Permian branchiosaurid Apateon. Geological Society, London, Special Publications 339, 139149.

Schindler, T., 1997. Neue lithostratigraphische Leithorizonte im unteren Rotliegend des Saar-

Nahe-Beckens (U. Perm, SW-Deutschland). 1. Leithorizonte der lithostratigraphischen Einheit Mitteilungen 26, 37-44.

Schneider, J.W., Werneburg, R., 2012. Biostratigraphie des Rotliegend mit Insekten und Amphibien. In: Deutsche Stratigraphische Kommission (eds.) Stratigraphie von Deutschland

X. Rotliegend. Teil I: Innervariscische Becken. Schriftenreihe der Deutschen Gesellschaft für

Geowissenschaften 61, 110-142.

Schneider, J.W., Lucas, S.G., Scholze, F., Voigt, S., Marchetti, L., Klein, H., Opluštil, S.,

Werneburg, R., Golubev, V.K., Barrick, J.E., Nemyrovska, T., Ronchi, A., Day, M.O.,

Silantiev, V.V., Rößler, R., Saber, H., Linnemann, U., Zharinova, V., Shen, S.-Z., 2020. Late

Paleozoic-early Mesozoic continental biostratigraphy - links to the Standard Global

Chronostratigraphic Scale. Palaeoworld 29, 186-238.

Schubnel, T., Desutter-Grandcolas, L., Legendre, F., Prokop, J., Mazurier, A., Garrouste, R., Grandcolas, P., Nel, A. 2019 (2020). To be or not to be: postcubital vein in insects revealed by microtomography. Systematic Entomology 45, 327-336. 
Sharov, A.G., 1968. Filogeniya ortopteroidnykh nasekomykh. Trudy Paleontologicheskogo Instituta, Akademiya Nauk S.S.S.R. 118, 1-216, Moskva. [in Russian, Translated in English in 1971: Phylogeny of the Orthopteroidea. Israel program for scientific translations, Keter Press, Jerusalem, 1-251.]

Uhl, D., 1999. Syncarids (Crustacea, Malacostraca) from the Stephanian D (Upper Carboniferous) of the Saar-Nahe-Basin (SW-Germany). Neues Jahrbuch für Geologie und Paläontologie Monatshefte 1999, 679-697.

Uhl, D., 2008. Die Paläoflora aus dem Rotliegend (Oberkarbon - Unterperm; Meisenheim Formation; M5) von Niedermoschel (Saar-Nahe-Becken, SW-Deutschland). Mainzer geowissenschaftliche Mitteilungen 36, 7-36.

Zalessky, M.D., 1928. Sur un nouvel insecte nevropteroïde du Permien du bassin de Kama. Bulletin de la Société Géologique de France (4) 28, 387-390.

Zalessky, M.D., 1929. On the new insects from the Permian basins of Kama, Viatka and Belaia rivers. Trudy Obshchestva Estestvoispytatelej pri Kazansskom y Universitet Kazan 52, 48-75. [in Russian.]

Zalessky, G.M., 1934. Sur deux représentants permiens nouveaux de l'ordre des Protorthoptères. Annales de la Société Entomologique de France 103, 149-158.

Figure captions:

Fig. 1. Simplified geographical position and geology (with approximate ages, mya) of the SaarNahe Basin, with both the 'Niedermoschel black pelite' and the Sitters locality indicated by black asterisks (modified after Sanchez et al., 2010). 
Fig. 2. Palatinoedischia elongata nov. gen., nov. sp., holotype PE 2018/5000-LS. Photographs of forewing, whitened with MgO. A. Part PE 2018/5000-LSa. B. Counterpart PE 2018/5000399 clockwise. Scale bars: $10 \mathrm{~mm}$.

400

Fig. 3. Palatinoedischia elongata nov. gen., nov. sp., holotype PE 2018/5000-LS. Drawings. wing venation combined from part and counterpart. Scale bar: $10 \mathrm{~mm}$.

404

405

406

407 



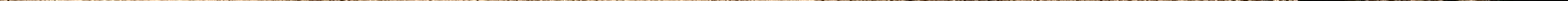


$A$

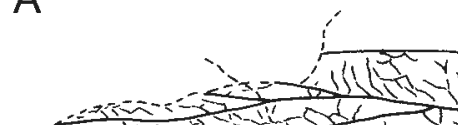

Fin

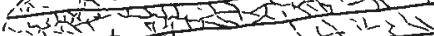
कोडी

inis

B
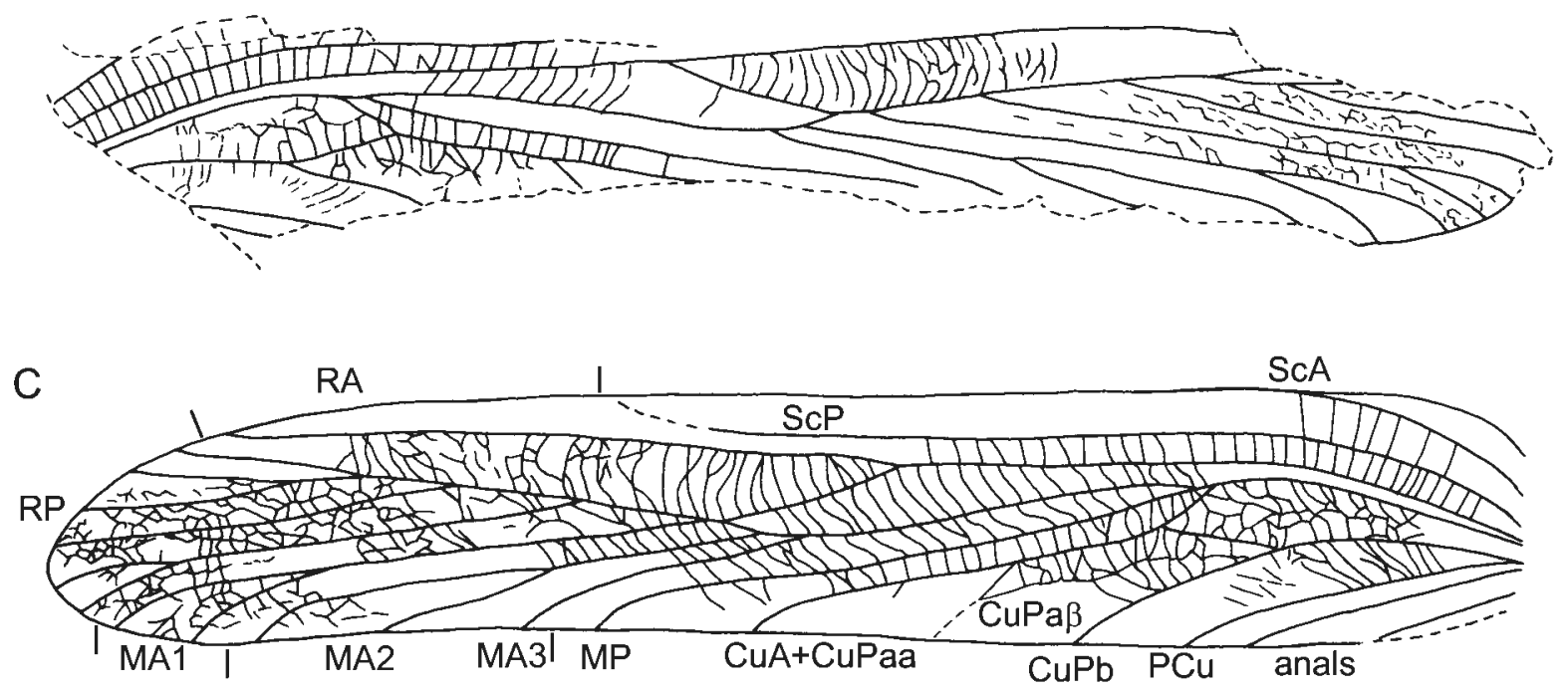